\title{
Merkel cell carcinoma arising from postoperative scar: An unusual presentation
}

\section{Mualla Polat, ๑ Tekden Karapınar, ๑ Hesna Müzeyyen Astarcı*, ๑ Bengü Tuman, ๑ Metin Görgü**}

Bolu Abant Izzet Baysal University Faculty of Medicine, Department of Dermatology; *Department of Pathology; **Department of Plastic and Reconstructive Surgery, Bolu, Turkey

\begin{abstract}
Merkel cell carcinoma (MCC) is an aggressive and uncommon primary cutaneous neuroendocrine cancer. With unknown pathogenesis, immunosuppression, ultraviolet radiation, Merkel cell polyomavirus, and arsenic exposure are the risk factors. Reported here is a rare case of MCC developing on a scar tissue.

Keywords: Cancer, Merkel cell carcinoma, scar

Öz

Merkel hücreli karsinom (MHK) agresif ve nadir görülen bir primer kutanöz nöroendokrin kanserdir. Kesin patogenez bilinmemektedir. İmmünosüpresyon, ultraviyole radyasyon, Merkel hücreli polyomavirüs ve arsenik maruziyeti risk faktörleridir. Biz bu olgu sunumunda skar dokusu üzerinde gelişen nadir MHK olgusunu sunuyoruz.

Anahtar Kelimeler: Kanser, Merkel hücreli karsinom, skar

\section{Introduction}

Merkel cell carcinoma (MCC) is an uncommon and aggressive neuroendocrine cutaneous neoplasm, frequently occurring on sun-exposed areas in elderly people ${ }^{1-3}$. Risk factors include ultraviolet (UV) radiation, psoralen and ultraviolet A (PUVA) treatment, immunosuppression, arsenic exposure, statin therapy, and Merkel cell polyomavirus (MCPV)².

\section{Case Report}

A 54-year-old female patient presented with a three-month history of a non-tender lump on her knee. She had an operation for meniscopathy six years ago, without history of immunosuppressant drug usage, immunosuppressive disease, excessive UV radiation exposure, viral illness, or arsenic exposure. Dermatologic examination revealed a well-defined, violaceous, hypertrophic, approximately $2 \mathrm{~cm}$ in diameter, and non-tender nodule on the left knee arising
\end{abstract}

Address for Correspondence/Yazışma Adresi: Mualla Polat MD, Bolu Abant İzzet Baysal University Faculty of Medicine, Department of Dermatology, Bolu, Turkey Phone: +90 3742534656 E-mail: polatmualla@gmail.com Received/Geliş Tarihi: 20.07.2020 Accepted/Kabul Tarihi: 30.01.2021 ORCID: orcid.org/0000-0001-9226-5134

Cite this article as: Polat M, Karapınar T, Astarcı HM, Tuman B, Görgü M. Merkel cell carcinoma arising from postoperative scar: An unusual presentation. Turkderm-Turk Arch Dermatol Venereol 2021;55:96-8.

CCopyright 2021 by Turkish Society of Dermatology and Venereology

Turkderm - Turkish Archives of Dermatology and Venereology published by Galenos Yayinevi. 
from a postoperative scar (Figure 1A, B). A dermal infiltration by small round cells with scant cytoplasm and hyperchromatic nuclei was revealed in a histopathologic examination of a punch biopsy (Figure 2AC). Tumor cells were strongly positive for neural cell adhesion molecule (CD56), neuron-specific enolase (NSE), and synaptophysin. Cytokeratin 19 (CK19) and CK20 exhibited paranuclear staining with a dot-like positivity (Figure $2 \mathrm{~d}$ ), but were negative for human melanoma black-45, S-100 protein, thyroid transcription factor-1 (TTF-1), and chromogranin A. A diagnosis of MCC was made based on histopathological and immunohistochemical features.

The primary knee lesion was removed surgically with a $2 \mathrm{~cm}$ margin. The patient was referred for oncology to determine distant metastasis and immunosuppression status due to bilaterally detected reactive inguinal lymph nodes. Inguinal lymph node dissection was performed after a positive sentinel node biopsy. Computed tomography and ultrasonography of the abdomen and thorax did not reveal any systemic involvement. No pathological blood test values were acquired. The MCC was staged as IB according to the 2015 European consensusbased interdisciplinary guideline, and the patient was referred for radiotherapy ${ }^{4}$.

\section{Discussion}

More than $50 \%$ of MCCs occur in the head and neck followed by the extremities, trunk, and buttocks ${ }^{2}$. MCC has a high propensity for local recurrence along with regional node and distant metastases. Risk factors include sun damage, immunosuppression, arsenic exposure,

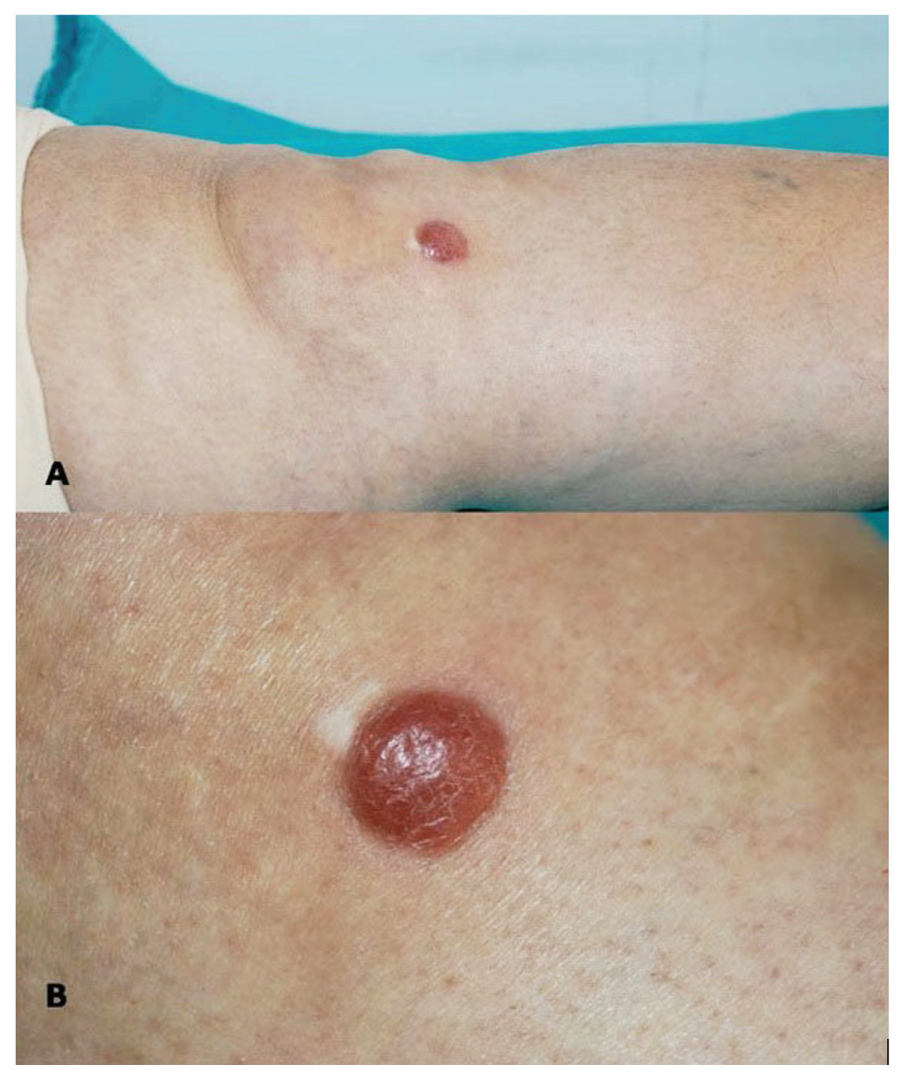

Figure 1. A) Violaceous, dome-shaped, and non-tender nodule on the left knee. B) Close-up view of the nodular lesion

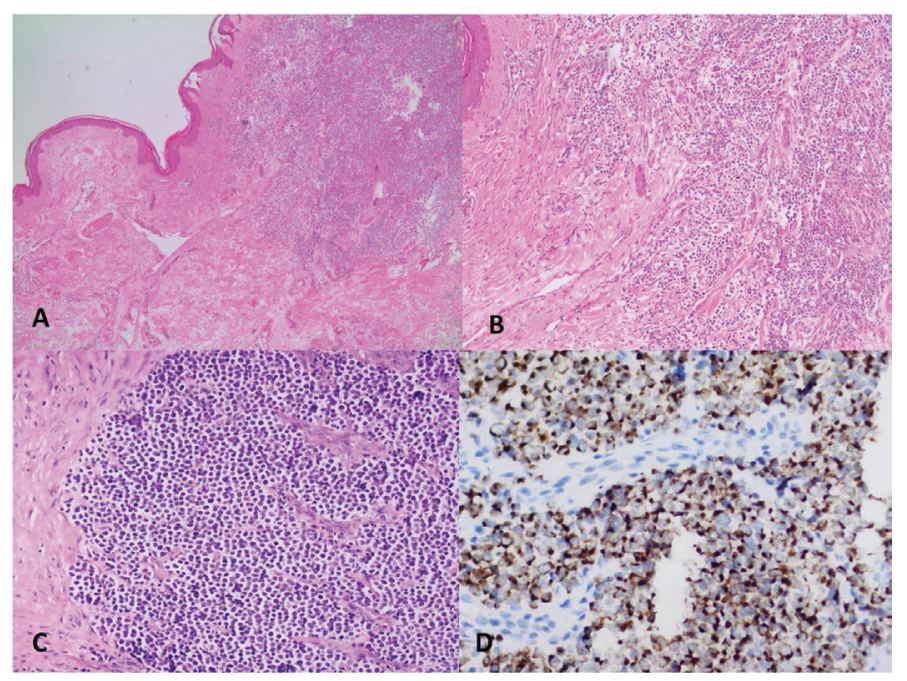

Figure 2. A) Tumor cells adjacent to the hypertrophic scar characterized by coarse and irregular collagen bundles [hematoxylin and eosin (H\&E), x4]. B) Tumoral infiltration between collagen bundles (H\&E, x20). C) Close-up view of Merkel cells (H\&E, x40). D) Cytokeratin 20 positivity in Merkel cell carcinoma with typical perinuclear dot-like staining pattern (magnification, x400)

statin therapy, PUVA treatment, and MCPV ${ }^{2}$. MCC presents as a solitary, rapidly growing, firm, asymptomatic, and red-or purple-colored nodule. Histologically, MCC consists of sheets of monomorphous small blue cells, which may confuse it with other closely associated skin neoplasms, such as small cell lung cancer, cutaneous lymphoma, melanoma, and Ewing's sarcoma ${ }^{3}$.

Immunohistochemistry is often used to diagnose MCC $^{5}$. Merkel cell tumors stain positively for NSE, synaptophysin, and chromogranin A. MCC is distinguished by expression of certain epithelial markers, such as CK20, characterized by paranuclear dot-like staining ${ }^{4}$. MCC is rarely negative for CK20 and rarely positive for TTF-1, whereas metastatic small-cell carcinoma of the lung is rarely positive for CK20. All available markers should be used to make an accurate diagnosis. For example, MCPV is absent in non-cutaneous neuroendocrine carcinomas, thus screening for MCPV may differentiate MCC from other neuroendocrine tumors $^{6}$.

A localized MCC tumor has the best prognosis. Lymph node status is the most important independent predictor ${ }^{4}$. A 1-2 cm excision margin is recommended in the head and neck region for biopsy, and complete histological inspection of the margins of the excised material during the microscopically controlled surgery is required. Sentinel lymph node biopsy is recommended regardless of tumor size. Electrochemotherapy or radiation therapy with or without chemotherapy may be used when surgical excision is not feasible 4 .

The median age at MCC diagnosis is 75-80 years ${ }^{6}$. MCC may have originated, relatively early in our 56-year-old patient without predisposing factors, due to trauma from a meniscopathy surgery six years ago. Three reported cases of MCC are formed on scars. An 85-year-old man presented with a six-month history of a firm and reddish nodule on a sternotomy scar ${ }^{7}$. A 70-year-old man presented with a one-year history of a violaceous plaque on the right leg vein graft donor site ${ }^{8}$. A 66-yearold female developed MCC along the traumatic suture scar in the nasal 
vestibule ${ }^{9}$. To our knowledge, ours is the fourth case of MCC occurring on scar tissue. The development of various cutaneous malignancies on scars has been well documented; per our case and others, MCC can also rarely arise in this manner. Clinicians must be vigilant in identifying and assessing new lesions appearing on scars.

\section{Ethics}

Informed Consent: Informed consent form was obtained from the patient.

Peer-review: Externally peer-reviewed.

\section{Authorship Contributions}

Surgical and Medical Practices: M.P., T.K., H.M.A., B.T., M.G., Concept: M.P., T.K., H.M.A., B.T., M.G., Design: M.P., T.K., H.M.A., B.T., M.G. Data Collection or Processing: M.P., T.K., H.M.A., B.T., M.G., Analysis or Interpretation: M.P., T.K., H.M.A., B.T., M.G., Literature Search: M.P., T.K., H.M.A., B.T., M.G., Writing: M.P., T.K., H.M.A., B.T., M.G.,

Conflict of Interest: No conflict of interest was declared by the authors.

Financial Disclosure: The authors declared that this study received no financial support.

\section{References}

1. Toker C: Trabecular carcinoma of the skin. Arch Dermatol 1972;105:107-10.

2. Schick BA, Tobe JS, Joseph MG, Rouse TB, Gabril MY: Incidental Merkel cell carcinoma in a cutaneous horn: a case report. Dermatol Pract Concept 2015;5:47-50.

3. He W, Zhang D, Jiang J, Chen Y, Wu C: Merkel cell carcinoma in the left groin: A case report and review of the literatur. Oncol Lett 2015;9:1197-200.

4. Lebbe C, Becker JC, Grob JJ, et al: Diagnosis and treatment of Merkel Cell Carcinoma. European consensus-based interdisciplinary guideline. Eur J Cancer 2015;51:2396-403.

5. Wong HH, Wang J: Merkel cell carcinoma. Arch Pathol Lab Med 2010;134:1711-6.

6. Becker JC, Stang A, DeCaprio JA, et al: Merkel cell carcinoma. Nat Rev Dis Primers 2017;3:17077.

7. Grippaudo FR, Costantino B, Santanelli F: Merkel cell carcinoma on a sternotomy scar: atypical clinical presentation. J Clin Oncol 2015;33:e22-4.

8. Ranario JS, Wolthoff AJ, Hope RH, Stetson CL, Ronaghan CA: Merkel cell carcinoma in a vein graft donor site. Cutis 2016;97:364-7.

9. Jiang P, Lai J: Merkel Cell Carcinoma Clinically Mimicking a Traumatic Suture Scar in the Nasal Vestibule: Earlier Diagnosis for Better Prognosis. Anticancer Res 2020:40:1123-6. 